\title{
Soil organic carbon, dehydrogenase activity, nutrient availability and leaf nutrient content as affected by organic and inorganic source of nutrient in mango orchard soil
}

\author{
T. Adak*, A. Singha, K. Kumar, S.K Shukla, A. Singh and V. Kumar Singh \\ Division of Crop Production, Central Institute for Subtropical Horticulture, Rehmankhera, Lucknow - 226101, Uttar Pradesh, \\ India. *Corresponding author : tarunadak@gmail.com
}

\begin{abstract}
Changes in soil organic carbon, dehydrogenase activity, nutrient availability and leaf nutrient concentrations in a mango orchard soil was evaluated from four years (2007-2011) field experiment on a Typic Ustocrepts soil of subtropical region in Lucknow, India. Organic (FYM, vermicompost, mulching, Azotobacter, PSM and Trichoderma harzianum) and inorganic (N, P, K) substrates were applied each year within the tree basin. It was observed that soil and leaf nutrients concentrations significantly increased in organic and inorganic amended soils as compared to control. Vermicompost, organic mulching and microbial inoculation significantly enhanced soil organic carbon content, available nutrients, dehydrogenase activity and leaf nutrient concentrations. Dehydrogenase activity was highest (1.85 $\left.\mu \mathrm{g} \mathrm{TPF}^{-1} \mathrm{~h}^{-1}\right)$ in organically treated soils. Surface soil $(0-10 \mathrm{~cm}$ depth) showed higher dehydrogenase activity (1.29 to $\left.1.85 \mu \mathrm{g} \mathrm{TPF} \mathrm{g}{ }^{-1} \mathrm{~h}^{-1}\right)$ as compared to lower soil depths in all the treatments.
\end{abstract}

Keywords: Vermicompost, microbial inoculants, dehydrogenase activity, soil chemical properties, leaf nutrient dynamics

\section{Introduction}

India ranks first in the production of mangoes, accounting for nearly $50 \%$ of the total world production, widely cultivated in almost all the states, soil and climatic conditions. Malihabad region of Uttar Pradesh is one of the major contiguous mango producing belts. However, inappropriate production technologies have resulted in deterioration in soil quality, leading to soil organic matter losses and structural degradation affecting water, air and nutrient flows, and consequently poor plant growth and yield (Albiach et al., 2001; Ravishankar et al., 2010).
Mango orchards under alluvial soils of IndoGangetic belt are very poor in organic matter owing to high temperature and rainfall and intense microbial activities (Bhriguvanshi et al., 2012). Organic manure is generally applied to maintain soil health and sustainability in intense cropping systems (Singh et al., 2010). In this context, attention is given to increase the utilization of different kinds of organic wastes as organic sources of nutrition through composting, vermicomposting, organic mulching, bioinoculants, etc. Transformation of nutrients in soil is an enzyme 
mediated biochemical process facilitated by a group of microorganisms. Application of vermicompost increases nutrient content, enhances soil respiration and different enzymatic activities (Dehydrogenase, urease, $\beta$-glucosidase, phosphatase, arylsulfatase) and activates microorganisms in soil (Arancon et al., 2006; Tejada et al., 2010). Pramanik et al., (2007) demonstrated that the presence of several enzymes in vermicompost ultimately lead to improvement in health of the soil.

Microbial communities are important for the functioning of the ecosystem both in relation to direct interactions with plants and with regard to nutrient and organic matter cycling (Adak and Sachan, 2009). Application of microbial inoculants contributes significantly to the soil surface ecosystem by their organic acid secretions in decomposing soil organic matter, nutrient chelation, fixation and hormonal action (Zahir et al., 2004).

Orchard soil management differs from that of intensively cultivated agricultural land use systems (Rahman and Sugiyama, 2008; Rahman et al., 2011). Addition of organic and inorganic sources of nutrients influences soil properties and nutrient dynamics more often, micronutrients. Any shift in their content, interactions or relationship with other soil properties is therefore important to look into. Wide variability in soil organic carbon, micronutrients across different land use system and their variability due to soil management strategy have been reported by many workers (Kumar et al., 2009). Since, quantitative and/or qualitative information on the application of organic and inorganic substrates in mango orchard soils of subtropical India is meagre, the present study was intended to assess the changes in soil characteristics and leaf nutrient concentrations in an old alluvial mango orchard soil through integrated nutrient management.

\section{Materials and Methods}

\subsection{Site characteristics and experimental design}

This experiment was conducted in experimental farm of Central Institute for Sub-tropical Horticulture, Rehmankhera, Lucknow ( $26.54^{\circ} \mathrm{N}$ Latitude, $80.45^{\circ} \mathrm{E}$ Longitude and $127 \mathrm{~m}$ above mean sea level), Uttar Pradesh, India. The soil of the experimental site belongs to the major group of Indo-Gangetic alluvium with well drained sandy loam texture. Taxonomically, the soil is mixed hyperthermic Typic Ustocrepts, alkaline in nature with $\mathrm{pH}$ and electrical conductivity ranging from 6.64 to 8.18 (Mean 7.48) and 0.04 to $0.13 \mathrm{dS} / \mathrm{m}$ (mean $0.077 \mathrm{dS} / \mathrm{m}$ ) respectively. Organic carbon $(0.32 \%)$, available phosphorus $\left(4.5 \mathrm{mg} \mathrm{kg}^{-1}\right)$ and potassium (30.5 $\mathrm{mg} \mathrm{kg}^{-1}$ ) were low. DTPA extractable $\mathrm{Fe}, \mathrm{Mn}, \mathrm{Zn}$ and $\mathrm{Cu}$ content were also low in the soil $(2.232,1.961,0.176$ and $0.163 \mathrm{ppm}$ respectively). The field experiment was continuing from 2007 to 2011 with treatments consisting of different organic (FYM, Vermicompost, mulching) and inorganic (N, $\mathrm{P}_{2} \mathrm{O}_{5}, \mathrm{~K}_{2} \mathrm{O}$ ) sources of nutrition including bioinoculants (Azotobacter, phosphate solubilizing microbes - PSM and Trichoderma harzianum). Paddy straw was used as mulch at the rate of $5 \mathrm{~kg}$ per plant. Biofertilizers (Azotobacter, PSM and Trichoderma harzianum) were applied at rate of $100 \mathrm{~g}$ per plant. The nutrient contents in vermicompost were 1.57, 1.15 and $1.75 \% \mathrm{~N}, \mathrm{P}$ and $\mathrm{K}$ and 3320, 397, 112 and $48 \mathrm{mg} \mathrm{kg}^{-1}$ of $\mathrm{Fe}, \mathrm{Mn}, \mathrm{Zn}$ and $\mathrm{Cu}$, respectively while in FYM were $0.8,0.3$ and 0.92 $\% \mathrm{~N}, \mathrm{P}$ and $\mathrm{K}$ and $3135,222,75$ and $34 \mathrm{mg} \mathrm{kg}^{-1}$ of $\mathrm{Fe}$, $\mathrm{Mn}, \mathrm{Zn}$ and $\mathrm{Cu}$, respectively on dry weight basis. The experiment was laid out in a randomized block design with four replications. Mango cv Dashehari was planted in 2007 at a spacing of $10 \times 10 \mathrm{~m}$ with five treatments comprising $\mathrm{T}_{1}-10 \mathrm{~kg} \mathrm{FYM}+100,50,100 \mathrm{~g} \mathrm{~N}, \mathrm{P}$ and K/ tree /year of age (control), $\mathrm{T}_{2}-10 \mathrm{~kg} \mathrm{FYM}+100,50,100$ $\mathrm{g} \mathrm{N}, \mathrm{P}$ and $\mathrm{K} /$ tree / year of age + Azotobacter $+\mathrm{PSM}$ + Trichoderma harzianum + Organic mulching, $\mathrm{T}_{3}-100$, $50,100 \mathrm{~g} \mathrm{~N}, \mathrm{P}$ and $\mathrm{K} /$ tree / year of age + Azotobacter + PSM + Trichoderma harzianum + Organic mulching, $\mathrm{T}_{4}-5 \mathrm{~kg} \mathrm{FYM}+5 \mathrm{~kg}$ Vermicompost $+100,50,100$ $\mathrm{g} \mathrm{N}, \mathrm{P}$ and $\mathrm{K} /$ tree / year of age + Azotobacter + 
$\mathrm{PSM}+$ Trichoderma harzianum + Organic mulching and $\mathrm{T}_{5}-10 \mathrm{~kg}$ Vermicompost $+100,50,100 \mathrm{~g} \mathrm{~N}, \mathrm{P}$ and $\mathrm{K} /$ tree /year of age + Azotobacter + PSM + Trichoderma harzianum + Organic mulching. The treatments were applied in the tree basin in 1st week of October. Plants were watered weekly in winter at 2-3 days interval and in summer during first year of establishment. The irrigation was given at the interval of 8-10 days during winter and at weekly interval during summer months in second year onwards. The plants were covered with thatch for protection from frost injury during winter season. The plots were maintained weed free during the course of study and need based plant protection measures were adopted.

\subsection{Soil and leaf analysis}

Soil samples were collected from Ap horizons at 0-30 $\mathrm{cm}$ soil depth from the tree basin in all the treatments replication wise before fertilization each year. Samples were air dried at room temperatures and passed through a $2 \mathrm{~mm}$ sieve and homogenated. Soil $\mathrm{pH}$ and electrical conductivity (EC) was determined using standard protocol of Piper (1967). Soil organic carbon content was estimated by the standard dichromate oxidation method. Mineralizable nitrogen was estimated by distillation with alkaline $0.32 \%$ potassium permanganate (Subbiah and Asija 1956). Available phosphorus was estimated calorimetrically by blue color method after extraction with sodium bicarbonate solution (Olsen et al., 1954) and available potassium was extracted with neutral $1 \mathrm{~N} \mathrm{NH}_{4} \mathrm{OAc}$ (Hanway and Heidel, 1952) and measured by Atomic Absorption Spectrophotometer (AAS). Available $\mathrm{Zn}, \mathrm{Cu}, \mathrm{Mn}$ and $\mathrm{Fe}$ contents (DTPA extractable) in the soil were estimated by 'Chemito' AA203D model of atomic absorption spectrophotometer as per the procedure of Lindsay and Norvell (1978). For estimation of biological activity, a separate set of soil samples was collected from 0-10, 10-20 and 20-30 cm soil depths from the tree basin in all the treatments. Soil moisture was determined through gravimetric method and pooled data was presented. Dehydrogenase activity was estimated using 2, 3, 5 triphenyal tetrazolium chloride using $1 \mathrm{~g}$ of field moist soil $(<2 \mathrm{~mm})$ and expressed as $\mu \mathrm{g}$ of triphenylformazan (TPF) formed per gram of oven dry soil per 24 hours (Casida et al., 1964). Recently matured leaf samples (5-7 months old) were collected from the trees of each treatment, decontaminated by washing first with tap water and in $\mathrm{N} / 10 \mathrm{HCl}$ solution to remove residues of chemical spray materials on the leaf surface, followed by washing in single and double distilled water. Excess water on the surface of the leaves was removed by pressing between the folds of blotting paper and the leaves were dried in an oven at $48{ }^{\circ} \mathrm{C}$ for 72 hours. After complete drying, the samples were ground in a grinder and used for analysis. Oven dried leaf samples were analyzed for different nutrients after digesting $1 \mathrm{~g}$ leaf sample in di-acid mixture of nitric acid and perchloric acid (9:4), by standard analytical methods (Lindsay and Norvell, 1978). Nitrogen was estimated by micro-Kjeldahl method whereas $\mathrm{P}$ by vanadomolybdate yellow colour method (Piper, 1967). K and the micronutrients $\mathrm{Fe}, \mathrm{Mn}, \mathrm{Cu}$ and $\mathrm{Zn}$ were analyzed by using AAS.

\subsection{Statistical analysis}

The data of all soil factors was analyzed statistically by standard analysis of variance (ANOVA) and differences were separated by least significant difference (LSD) using SAS version 9.3 (SAS Institute, Inc., Cary, NC, USA 1990). For statistical analysis of data, MicrosoftExcel software (Microsoft Corporation, USA) was used and significant differences were determined at $\operatorname{LSD}(p=0.05)$.

\section{Results and Discussion}

\subsection{Soil organic carbon, available $N, P$ and $K$ dynamics}

The soil organic carbon (SOC) content improved significantly over the years of experimentation. Initially it was in the range of $0.18-0.31$ per cent across 
all the treatments in 2008-09 and later on improved to a level of 0.33-0.60 per cent in 2010-11. Pooled mean data showed improvement in SOC content between 0.27 and $0.45 \%$ among various treatments (Figure 1). The organic carbon build up over the years was a function of microbial activity and organic matter decomposition. Highest SOC $(0.45 \%)$ was observed in the treatment, 10 $\mathrm{kg}$ Vermicompost $+100,50,100 \mathrm{~g} \mathrm{~N}, \mathrm{P}$ and K / tree /year of age + Azotobacter + PSM + Trichoderma harzianum + organic mulching. The control plot $\left(\mathrm{T}_{1}\right)$, where only FYM and inorganic fertilizers were applied, had $0.27 \%$ SOC content. Thus, application of microorganisms and organic mulching played significant role in organic matter build up in the soil. In a sandy silty loam soil, Albiach et al. (2001) found significant increase in soil organic matter after four years of organic amendment application to a horticultural soil. The volumetric soil moisture content $(\theta \mathrm{v})$ in mango orchard soils varied from 10 to 22 per cent. Pooled data (Figure 2) showed the variability across different treatments. Organic mulch treated soils had marginally higher $\theta \mathrm{v}$ as compared to the control $\left(\mathrm{T}_{1}\right)$ with no mulching. Positive effect of different nutrient sources on availability of $\mathrm{N}, \mathrm{P}$ and $\mathrm{K}$ was inferred from this study (Table 1). Available nitrogen (N) was more in the treatment receiving vermicompost as compared to FYM. The maximum available $\mathrm{N}$ was observed as $71.7 \mathrm{mg} \mathrm{kg}^{-1}$ in $\mathrm{T}_{5}$ treatment as compared to $48.4 \mathrm{mg} \mathrm{kg}^{-1}$ in $\mathrm{T}_{1}$. The build up of available nitrogen was significant across the treatments and was more dependent on addition of vermicompost than FYM in soil.
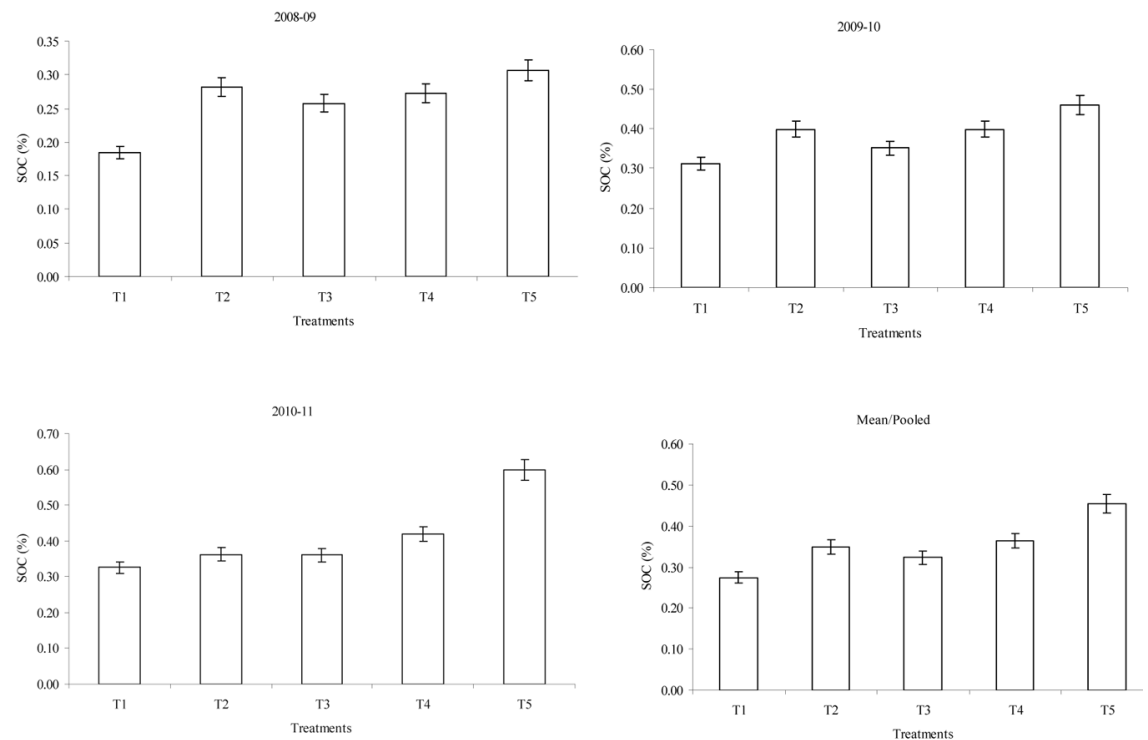

Figure 1. Effects of various substrates on SOC content (\%) in different treatments during 2008-09, 2009-10, 201011 and pooled mean over years. SOC content was significantly improved over the years of organic amendment application. All plots receiving vermicompost had significantly more SOC content $(p<0.05)$ than plots that received inorganic fertilizers only. Means were statistically significant and differences were concluded at $(p<0.05)$ as per the SAS 9.0 statistical software. 


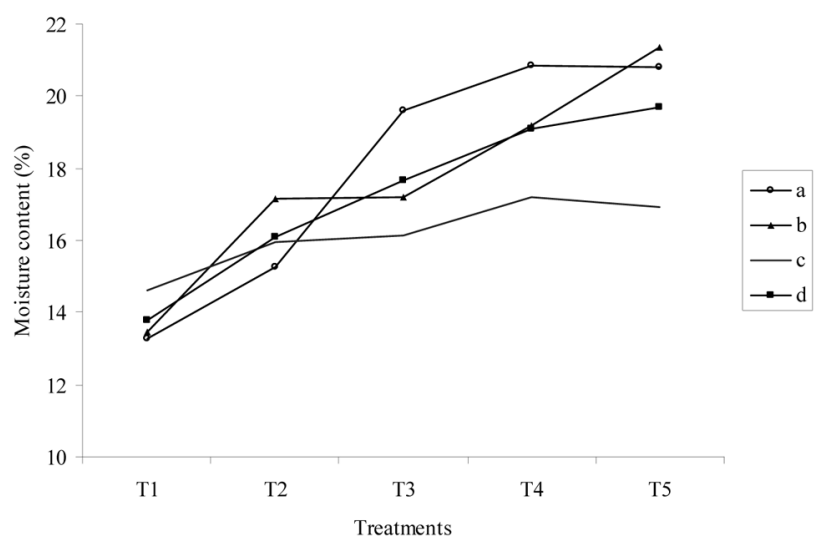

Figure 2. Mean volumetric moisture content $(\theta \mathrm{v})$ in mango orchard soils. a, b, c and d stands for soil samples at 0-10, $10-20,20-30$ and pooled 0-30 cm soil depth. All plots receiving organic sources had significantly more $\theta \mathrm{v}(p<0.05)$ than plots that received inorganic fertilizers only. The statistical significance was drawn using SAS at $p<0.05$.

The available phosphate although improved significantly in different treatments over the years in the orchard soil, the build up was more significant in treatments receiving vermicompost as an organic source. The available $\mathrm{P}$ increased from $8.1-12.8 \mathrm{mg}$ $\mathrm{kg}^{-1}$ in $2008-09$ to 21.1 to $31.1 \mathrm{mg} \mathrm{kg}^{-1}$ in $2010-11$ in the soil due to integrated nutrient management scheduling. The pooled data indicated improvement in $\mathrm{P}$ availability in vermicompost and microbial inoculants added soils (18.0 to $24.0 \mathrm{mg} \mathrm{kg} \mathrm{kg}^{-1}$ ) as compared to $\mathrm{T}_{1}$. Application of vermicompost in some treatments resulted in higher $\mathrm{P}$ availability $(24.0 \mathrm{mg}$ $\left.\mathrm{kg}^{-1}\right)$ as compared to its absence and FYM application in $\mathrm{T}_{2}$ treatment $\left(18.0 \mathrm{mg} \mathrm{kg}^{-1}\right)$. Inclusion of mulching and microbial inoculants resulted in the release of more $\mathrm{P}$ from soil nutrient pool and organic substrates. The $\mathrm{K}$ availability was significantly improved in the mango orchard soil as a function of nutrient management strategy. Application of microbial inoculants and mulching had showed significant improvement in $\mathrm{K}$ availability ( 83.9 to $111.5 \mathrm{mg} \mathrm{kg}^{-1}$ ) as compared to $62.9 \mathrm{mg} \mathrm{kg}^{-1}$ in $\mathrm{T}_{1}$ treatment. The mulching might have created congenial environment for microbial activity and nutrient release in the rhizosphere.

The use of organic and inorganic sources of nutrients has been viewed as an important soil management strategy to increase soil organic matter, provide nutrients and improve microbial activity (Tiwari et al., 1989). The results are conditioned by the composition of amendment, the rate of application and the soil type (Albiach et al., 2001; Basak et al., 2012). Even when vermicompost was added as an amendment to a horticultural soil, improvement in soil physical, chemical and biological properties was revealed (Atiyeh et al., 2000; Arancon et al., 2006). Improvement in organic carbon and available NPK in soils may be due to secretion of organic acids released from application of vermicompost, microbial inoculants and organic mulching in presence or absences of inorganic fertilizers. Actually, vermicompost is an earthworm processed product, rich in humic substances which act as a buffering agent for soil $\mathrm{pH}$. Results of the present experiment suggested the positive side of nutrient recycling through vermicomposting produce nutrientrich soil amendments. Application of vermicompost 
not only increased the nutrient content but also improved enzymatic activity of soil. Due to narrower range of $\mathrm{C} / \mathrm{N}$ ratios of vermicompost, application of vermicompost hastens the mineralization rate, which in turn increases the mineralizable $\mathrm{N}$ content in soil. Solubilization of phosphorus to make it available to plants is the most important aspects of fertilizer management in fruit trees. Due to low initial fertility status of orchard soils of semiarid regions, application of vermicompost may be fruitful as it releases phosphate ions from soil ion exchange sites and increases their concentration in soil solution. Vermicompost is also rich in several microorganisms that produce a number of organic acids specially oxalic acid, which facilitates the solubilization of bound phosphorus and potassium in soil (Zhang et al., 2000). Higher protease and acid phosphate activity in vermicompost treated soils might be responsible for higher nitrogen and phosphorus content in soil. Tejada et al., (2010) also found the improvement in biochemical properties of soil due to vermicompost application. Binet and Trehem, (1992) propose that soil mineralizable nitrogen content increases up to $10 \%$ after only 85 days of earthworm cast application. Amylase, protease, and phosphatase enzyme govern the transformation of carbon, nitrogen and phosphorus from organically bound forms to plant available forms in soil. Urease enzyme converts urea, the most commonly used nitrogenous fertilizer, to the plant available nitrate form.

\subsection{Dehydrogenase activity}

Dehydrogenase activity (DHA) closely followed the pattern of the organic matter and available NPK build up in the soil in various treatments. Its magnitude was higher in surface soil $(0-10 \mathrm{~cm})$ as compared to the deeper layers (Figure 3). It varied from 0.71 to $1.85 \mu \mathrm{g}$ TPF $\mathrm{g}^{-1} \mathrm{~h}^{-1}$ in $0-10 \mathrm{~cm}$ soil and lowed down to 0.68 $0.96 \mu \mathrm{g} \mathrm{TPF} \mathrm{g}{ }^{-1} \mathrm{~h}^{-1}$ in 20-30 $\mathrm{cm}$ soil depth.

Table 1. Effect of organic and inorganic sources of nutrients on available N, P and K in soil

\begin{tabular}{lccccc}
\hline & Treatments & $\mathbf{2 0 0 8 - 0 9}$ & $\mathbf{2 0 0 9 - 1 0}$ & $\mathbf{2 0 1 0 - 1 1}$ & Mean \\
\hline & $\mathrm{T}_{1}$ & $33.5 \pm 1.5$ & $52.5 \pm 1.1$ & $58.0 \pm 4.4$ & $48.4 \pm 2.1$ \\
Available & $\mathrm{T}_{2}$ & $44.5 \pm 4.1$ & $64.8 \pm 5.3$ & $65.3 \pm 1.5$ & $57.8 \pm 2.5$ \\
$\mathrm{~N}\left(\mathrm{mg} \mathrm{kg}^{-1}\right)$ & $\mathrm{T}_{3}$ & $43.0 \pm 1.4$ & $55.3 \pm 6.8$ & $65.3 \pm 4.5$ & $54.5 \pm 1.1$ \\
& $\mathrm{~T}_{4}$ & $50.8 \pm 2.2$ & $68.0 \pm 4.9$ & $74.5 \pm 1.0$ & $64.4 \pm 2.2$ \\
& $\mathrm{~T}_{5}$ & $55.5 \pm 1.7$ & $73.3 \pm 2.0$ & $86.3 \pm 5.9$ & $71.7 \pm 1.4$ \\
& $\mathrm{LSD}(\mathrm{p}=0.05)$ & 2.23 & 3.55 & 4.17 & 5.17 \\
Available & & & & \\
$\mathrm{P}\left(\mathrm{mg} \mathrm{kg}^{-1}\right)$ & $\mathrm{T}_{1}$ & $8.1 \pm 0.5$ & $14.5 \pm 2.1$ & $21.1 \pm 2.4$ & $14.6 \pm 6.5$ \\
& $\mathrm{~T}_{2}$ & $10.1 \pm 0.7$ & $19.8 \pm 6.0$ & $24.0 \pm 2.8$ & $18.0 \pm 7.1$ \\
& $\mathrm{~T}_{3}$ & $10.8 \pm 0.9$ & $22.3 \pm 2.0$ & $24.7 \pm 4.4$ & $19.2 \pm 7.4$ \\
& $\mathrm{~T}_{4}$ & $11.0 \pm 0.2$ & $22.1 \pm 4.2$ & $26.5 \pm 3.0$ & $19.9 \pm 7.9$ \\
Available & $\mathrm{T}_{5}$ & $12.8 \pm 1.0$ & $28.0 \pm 3.7$ & $31.1 \pm 1.7$ & $24.0 \pm 9.7$ \\
K (mg kg $\left.^{-1}\right)$ & $\mathrm{LSD}(\mathrm{p}=0.05)$ & 0.32 & 0.86 & 0.81 & 0.64 \\
& & & & & \\
& $\mathrm{~T}_{1}$ & $33.3 \pm 4.2$ & $45.7 \pm 8.5$ & $109.6 \pm 4.5$ & $62.9 \pm 4.9$ \\
& $\mathrm{~T}_{2}$ & $44.5 \pm 6.4$ & $63.6 \pm 4.7$ & $143.4 \pm 3.9$ & $83.9 \pm 2.4$ \\
& $\mathrm{~T}_{3}$ & $42.4 \pm 5.7$ & $65.3 \pm 4.3$ & $135.4 \pm 3.5$ & $81.0 \pm 4.4$ \\
& $\mathrm{~T}_{4}$ & $47.7 \pm 1.1$ & $76.2 \pm 5.6$ & $158.4 \pm 1.2$ & $94.1 \pm 5.4$ \\
& $\mathrm{~T}_{5}$ & $52.1 \pm 0.8$ & $94.5 \pm 3.4$ & $188.0 \pm 1.9$ & $111.5 \pm 6.5$ \\
& $\mathrm{LSD}(\mathrm{p}=0.05)$ & 1.99 & 2.26 & 6.06 & 3.76
\end{tabular}



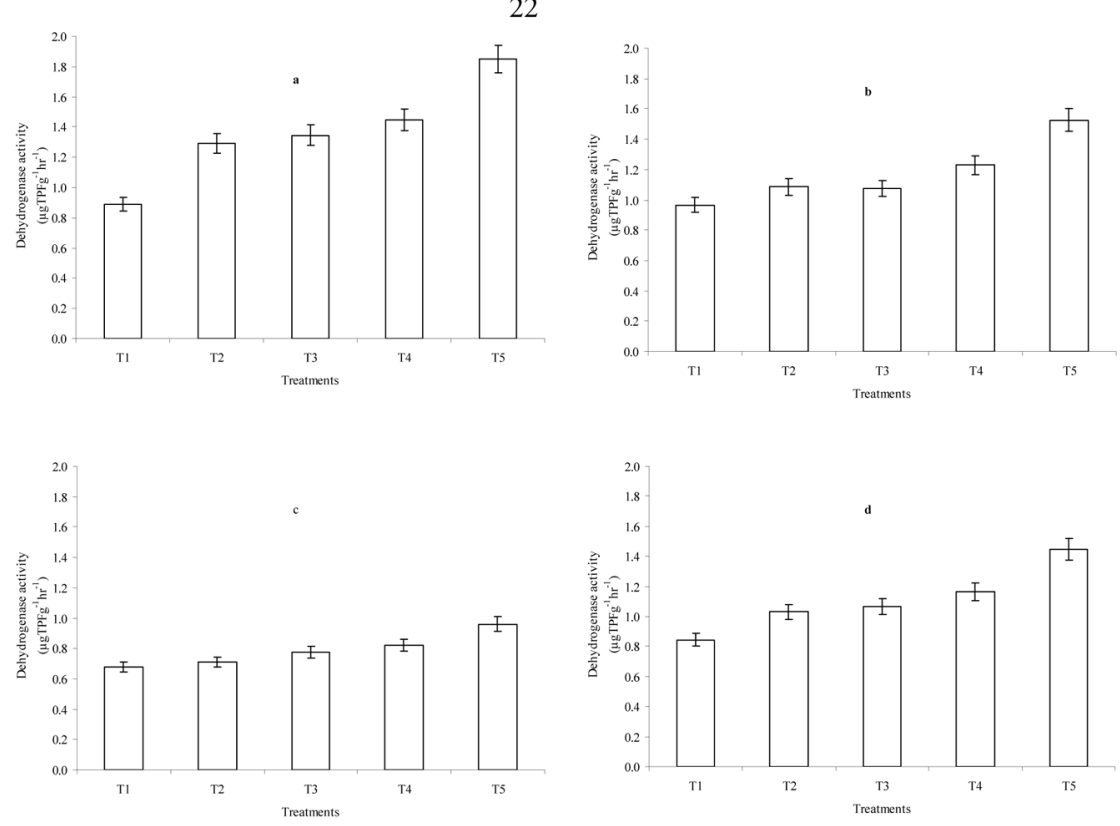

Figure 3. Mean dehydrogenase activity $\left(\mu \mathrm{g} T P F g^{-1} h^{-1}\right)$ in mango orchard soils. $a, b, c$ and d stands for soil samples at $0-10,10-20,20-30$ and pooled mean $0-30 \mathrm{~cm}$ soil depth. All plots receiving vermicompost had significantly more dehydrogenase activity $(p<0.05)$ than plots that received inorganic fertilizers only. The statistical significance and differences were concluded using SAS at $p<0.05$.

The mean dehydrogenase activity $\left(1.37 \mu \mathrm{g}\right.$ TPF $\mathrm{g}^{-1}$ $\mathrm{h}^{-1}$ ) was significantly higher in $0-10 \mathrm{~cm}$ soil depth and decreased with soil depth $\left(0.79 \mu \mathrm{g}\right.$ TPF $\left.\mathrm{g}^{-1} \mathrm{~h}^{-1}\right)$. It was interesting to note that the dehydrogenase activity was higher in vermicompost treated soils (1.07 to $1.35 \mu \mathrm{g}$ TPF $\left.\mathrm{g}^{-1} \mathrm{~h}^{-1}\right)$ as compared to FYM $\left(0.94 \mu \mathrm{g}\right.$ TPF $\left.\mathrm{g}^{-1} \mathrm{~h}^{-1}\right)$. The positive effect of microbial inoculants and mulching on dehydrogenase activity was also revealed from this study as the dehydrogenase activity was higher across the depths as compared to the control. The effect of vermicompost on DHA was also higher as compared to FYM across different depth.

Soil dehydrogenase activity is a function of soil management system as it is directly or indirectly influenced by the orchard ground-floor management systems (Chu et al., 2007). Generally the enzyme activities in the soil were closely related to the organic matter content. Application of balanced amounts of nutrients and manures improved the organic matter and microbial biomass carbon status of soils, which corresponded with higher enzyme activity (Mandal et al, 2007). Dehydrogenase activity with application of organic sources might be linked to more substrate availability in the soil. This reflects the greater biological activity in the soil and the stabilization of extracellular enzymes through complexation with humic substances (Basak et al., 2013). It has been reported that the increase in dehydrogenase activity and microbial biomass were proportional to the addition of number and amount of 
nutrients (Manjaiah and Singh, 2001). In the present study, a similar trend was observed. According to Pramanik et al. (2010) dehydrogenase activity is influenced more by the quality than by the quantity of organic matter incorporated into soil. Thus, the stronger effects of vermicompost or microbial inoculants on dehydrogenase activity might be due to the more easily decomposable components of crop residues on the metabolism of soil microorganisms.

\subsection{Micronutrients availability}

The micronutrient availability in the soil treated with different organic and inorganic sources showed significant difference (Table 2). The DTPA-Fe content of the soils varied from 3.83 to $8.63 \mathrm{mg}$ $\mathrm{kg}^{-1}, 4.17$ to $8.27 \mathrm{mg} \mathrm{kg}^{-1}$ and 7.07 to $9.32 \mathrm{mg} \mathrm{kg}^{-1}$ in 2008-09, 2009-10 and 2010-11 respectively. Considering critical limits of $2 \mathrm{mg} \mathrm{kg}^{-1}$, the soils are sufficient in $\mathrm{Fe}$. However, the pooled data indicated that mango soils had around 6.8 to $8.74 \mathrm{mg} \mathrm{kg}^{-1} \mathrm{Fe}$ in Vermicompost, microbial consortia, mulching and inorganic substrate added soils, lowest Fe content being in $\mathrm{T}_{1}\left(5.02 \mathrm{mg} \mathrm{kg}^{-1}\right)$. There was continuous build up of available $\mathrm{Fe}$ in the soil due to various treatments which may be attributed to release from the organic sources because of increased microbial activities in the soil.

Table 2. Effect of organic and inorganic sources of nutrients on available micronutrients $\left(\mathrm{mg} \mathrm{kg}^{-1}\right)$ in orchard soil

\begin{tabular}{cccccc}
\hline & Treatments & $\mathbf{2 0 0 8 - 0 9}$ & $\mathbf{2 0 0 9 - 1 0}$ & $\mathbf{2 0 1 0 - 1 1}$ & Mean \\
\hline DTPA- & $\mathrm{T}_{1}$ & $3.83 \pm 0.93$ & $4.17 \pm 0.68$ & $7.07 \pm 1.23$ & $5.02 \pm 1.78$ \\
extractable & $\mathrm{T}_{2}$ & $6.33 \pm 0.67$ & $5.68 \pm 1.08$ & $8.39 \pm 1.16$ & $6.80 \pm 1.41$ \\
$\mathrm{Fe}$ & $\mathrm{T}_{3}$ & $6.35 \pm 1.25$ & $6.00 \pm 1.94$ & $8.54 \pm 1.01$ & $6.96 \pm 1.38$ \\
& $\mathrm{~T}_{4}$ & $7.51 \pm 0.90$ & $7.08 \pm 1.29$ & $8.75 \pm 0.49$ & $7.78 \pm 0.87$ \\
& $\mathrm{~T}_{5}$ & $8.63 \pm 1.01$ & $8.27 \pm 1.04$ & $9.32 \pm 0.41$ & $8.74 \pm 0.53$ \\
& LSD $(\mathrm{p}=0.05)$ & 0.49 & 0.85 & 0.45 & 0.85 \\
DTPA- & & & & & \\
extractable & $\mathrm{T}_{1}$ & $3.53 \pm 1.27$ & $4.70 \pm 1.07$ & $6.03 \pm 0.31$ & $4.75 \pm 1.25$ \\
Mn & $\mathrm{T}_{2}$ & $6.34 \pm 1.72$ & $6.47 \pm 2.13$ & $7.45 \pm 1.23$ & $6.75 \pm 0.61$ \\
& $\mathrm{~T}_{3}$ & $7.08 \pm 2.47$ & $6.23 \pm 1.53$ & $6.69 \pm 0.72$ & $6.66 \pm 0.43$ \\
& $\mathrm{~T}_{4}$ & $7.39 \pm 1.54$ & $7.57 \pm 1.19$ & $7.56 \pm 0.48$ & $7.50 \pm 0.10$ \\
& $\mathrm{~T}_{5}$ & $8.95 \pm 0.97$ & $8.74 \pm 1.49$ & $9.13 \pm 1.27$ & $8.94 \pm 0.20$ \\
DTPA- & LSD $(\mathrm{p}=0.05)$ & 0.46 & 1.22 & 0.41 & 0.23 \\
extractable & & & & & \\
$\mathrm{Zn}$ & $\mathrm{T}_{1}$ & $0.65 \pm 0.23$ & $0.63 \pm 0.63$ & $1.09 \pm 0.47$ & $0.79 \pm 0.26$ \\
& $\mathrm{~T}_{2}$ & $1.22 \pm 0.42$ & $1.59 \pm 0.76$ & $2.32 \pm 1.26$ & $1.71 \pm 0.56$ \\
& $\mathrm{~T}_{3}$ & $1.31 \pm 0.23$ & $1.43 \pm 0.25$ & $1.10 \pm 0.51$ & $1.28 \pm 0.16$ \\
& $\mathrm{~T}_{4}$ & $1.34 \pm 0.55$ & $1.57 \pm 1.28$ & $3.17 \pm 1.59$ & $2.02 \pm 1.00$ \\
& $\mathrm{~T}$ & $1.88 \pm 0.13$ & $2.14 \pm 0.89$ & $4.13 \pm 1.08$ & $2.72 \pm 1.23$ \\
DSD $(\mathrm{p}=0.05)$ & 0.06 & 0.36 & 0.60 & 0.35 \\
DTPA- & & & & & \\
Cu & $\mathrm{T}_{1}$ & $0.32 \pm 0.11$ & $0.95 \pm 0.13$ & $1.72 \pm 0.36$ & $0.99 \pm 0.70$ \\
& $\mathrm{~T}_{2}$ & $0.45 \pm 0.09$ & $1.67 \pm 0.60$ & $2.55 \pm 0.43$ & $1.55 \pm 1.05$ \\
& $\mathrm{~T}_{3}$ & $0.49 \pm 0.19$ & $1.89 \pm 1.01$ & $3.11 \pm 0.56$ & $1.83 \pm 1.31$ \\
& $\mathrm{~T}_{4}$ & $0.60 \pm 0.16$ & $2.36 \pm 0.79$ & $3.54 \pm 0.68$ & $2.17 \pm 1.48$ \\
& $\mathrm{~T}$ & $0.84 \pm 0.15$ & $5.01 \pm 0.83$ & $5.49 \pm 2.77$ & $3.78 \pm 2.56$ \\
5 & & & 1.01 & 0.19 & 1.25 \\
& & & & &
\end{tabular}


Table 3. Foliar major nutrient concentrations, $\%$ (mean \pm standard deviations) in mango as influenced by organic and inorganic sources of nutrition

\begin{tabular}{cccccc}
\hline & Treatments & $\mathbf{2 0 0 8 - 0 9}$ & $\mathbf{2 0 0 9 - 1 0}$ & $\mathbf{2 0 1 0 - 1 1}$ & Mean \\
\hline \multirow{4}{*}{ Nitrogen } & $\mathrm{T}_{1}$ & $1.10 \pm 0.1$ & $1.06 \pm 0.2$ & $1.41 \pm 0.3$ & $1.19 \pm 0.2$ \\
& $\mathrm{~T}_{2}$ & $1.33 \pm 0.2$ & $1.35 \pm 0.1$ & $1.49 \pm 0.3$ & $1.39 \pm 0.1$ \\
& $\mathrm{~T}_{3}$ & $1.27 \pm 0.1$ & $1.20 \pm 0.2$ & $1.45 \pm 0.4$ & $1.31 \pm 0.1$ \\
& $\mathrm{~T}_{4}$ & $1.35 \pm 0.2$ & $1.37 \pm 0.2$ & $1.61 \pm 0.2$ & $1.44 \pm 0.1$ \\
& $\mathrm{~T}_{5}$ & $1.37 \pm 0.1$ & $1.49 \pm 0.1$ & $1.61 \pm 0.3$ & $1.49 \pm 0.1$ \\
& $\mathrm{LSD}(\mathrm{p}=0.05)$ & 0.02 & 0.02 & 0.06 & 0.01 \\
& & & & & \\
Phosphorus & $\mathrm{T}_{1}$ & $0.10 \pm 0.01$ & $0.17 \pm 0.03$ & $0.14 \pm 0.03$ & $0.14 \pm 0.03$ \\
& $\mathrm{~T}_{2}$ & $0.12 \pm 0.03$ & $0.17 \pm 0.01$ & $0.16 \pm 0.06$ & $0.15 \pm 0.02$ \\
& $\mathrm{~T}_{3}$ & $0.11 \pm 0.01$ & $0.16 \pm 0.03$ & $0.16 \pm 0.06$ & $0.14 \pm 0.02$ \\
& $\mathrm{~T}_{4}$ & $0.13 \pm 0.02$ & $0.17 \pm 0.04$ & $0.17 \pm 0.03$ & $0.16 \pm 0.02$ \\
& $\mathrm{~T}_{5}$ & $0.13 \pm 0.01$ & $0.18 \pm 0.04$ & $0.18 \pm 0.02$ & $0.16 \pm 0.03$ \\
& $\mathrm{LSD}(\mathrm{p}=0.05)$ & 0.001 & 0.001 & 0.002 & 0.0005 \\
& & & & & \\
& $\mathrm{~T}_{1}$ & $0.23 \pm 0.1$ & $0.47 \pm 0.1$ & $0.55 \pm 0.1$ & $0.51 \pm 0.04$ \\
& $\mathrm{~T}_{2}$ & $0.44 \pm 0.2$ & $0.54 \pm 0.04$ & $0.61 \pm 0.1$ & $0.57 \pm 0.04$ \\
& $\mathrm{~T}_{3}$ & $0.39 \pm 0.1$ & $0.53 \pm 0.03$ & $0.60 \pm 0.1$ & $0.56 \pm 0.03$ \\
& $\mathrm{~T}_{4}$ & $0.59 \pm 0.3$ & $0.54 \pm 0.05$ & $0.62 \pm 0.2$ & $0.58 \pm 0.03$ \\
& $\mathrm{~T}_{5}$ & $0.61 \pm 0.1$ & $0.56 \pm 0.1$ & $0.66 \pm 0.2$ & $0.61 \pm 0.05$ \\
& $\mathrm{LSD}(\mathrm{p}=0.05)$ & 0.02 & 0.002 & 0.01 & 0.001 \\
& & & & & \\
\hline \multirow{5}{*}{ Potassium } & & & &
\end{tabular}

Different treatments have shown significant effect on DTPA-Mn in the soil over the initial level of $1.96 \mathrm{mg}$ $\mathrm{kg}^{-1}$. Similarly, in case of DTPA-Zn and DTPA-Cu, it was observed that soils treated with vermicompost and microbial inoculants had higher availability $(2.72$ and $3.78 \mathrm{mg} \mathrm{kg}^{-1}$ respectively). In general, micronutrients contents were significantly enhanced over initial level primarily may be due to the application of different organic and inorganic nutrient sources. Considering the effects of different organic (FYM, vermicompost, mulching) and inorganic (N,, $\mathrm{K})$ sources of nutrition including bioinoculants (Azotobacter, PSM and Trichoderma harzianum), it was revealed that in mango ecosystem, highest content of $\mathrm{Fe}, \mathrm{Cu}, \mathrm{Mn}$ and $\mathrm{Zn}$ were recorded in the treatments comprising $10 \mathrm{~kg}$ vermicompost $+100,50,100 \mathrm{~g} \mathrm{~N}, \mathrm{P}$ and $\mathrm{K} /$ tree /year of age + Azotobacter + PSM + Trichoderma harzianum + organic mulching and the lowest in the treatment wherein organic mulching and bioinoculants were not included. Therefore the microbes and organic sources played significant role in nutrient acquisition and availability in the soil which is clearly evident for the dehydrogenase activity in the soil (Kumar et al., 2011).

\subsection{Leaf nutrient dynamics}

The present study indicated that foliar nutrient dynamics was significantly influenced by the application of organic and inorganic substrates to a low fertility mango orchard soil of subtropical region (Table 3). It was observed from the four year study that the nitrogen content of the leaves was in the sufficient level. The total nitrogen concentration in leaf was in the range of 1.06 to 1.61 per cent across the treatments and years. The highest $\mathrm{N}$ (1.49 per cent) was found in treatment $\mathrm{T}_{5}$ closely followed by $\mathrm{T}_{4}$ (1.44 per cent). The mean nitrogen content in leaf significantly increased over the years. The means value of total leaf nitrogen in $T_{5}$ and $T_{4}$ were significantly higher than $\mathrm{T}_{1}$. The pattern of soil available $\mathrm{N}$ and leaf $\mathrm{N}$ showed similar trend in different treatments. 
Table 4. Foliar micronutrient concentrations, $\mathrm{mg} \mathrm{kg}^{-1}$ (mean \pm standard deviations) in mango as influenced by organic and inorganic sources of nutrition

\begin{tabular}{|c|c|c|c|c|c|}
\hline & Treatments & 2008-09 & 2009-10 & 2010-11 & Mean \\
\hline & $\mathrm{T}_{1}$ & $105.5 \pm 9.8$ & $139.0 \pm 5.0$ & $137.8 \pm 4.5$ & $127.4 \pm 5.5$ \\
\hline \multirow[t]{5}{*}{$\mathrm{Fe}$} & $\mathrm{T}_{2}$ & $126.8 \pm 8.2$ & $151.8 \pm 8.3$ & $174.8 \pm 4.3$ & $151.1 \pm 9.6$ \\
\hline & $\mathrm{T}_{3}$ & $120.3 \pm 7.6$ & $151.0 \pm 8.0$ & $171.5 \pm 8.7$ & $147.6 \pm 8.0$ \\
\hline & $\mathrm{T}_{4}$ & $128.3 \pm 3.0$ & $157.5 \pm 8.4$ & $173.0 \pm 6.7$ & $152.9 \pm 8.5$ \\
\hline & $\mathrm{T}_{5}$ & $153.5 \pm 3.9$ & $173.0 \pm 3.0$ & $175.0 \pm 9.7$ & $167.2 \pm 9.7$ \\
\hline & $\operatorname{LSD}(p=0.05)$ & 3.14 & 5.67 & 5.75 & 4.32 \\
\hline \multirow{6}{*}{$\mathrm{Mn}$} & $\mathrm{T}_{1}$ & $84.0 \pm 4.7$ & $63.8 \pm 2.2$ & $158.3 \pm 8.1$ & $102.0 \pm 4.6$ \\
\hline & $\mathrm{T}_{2}$ & $100.0 \pm 9.3$ & $118.3 \pm 11.6$ & $167.0 \pm 6.1$ & $128.4 \pm 2.2$ \\
\hline & $\mathrm{T}_{3}$ & $90.3 \pm 4.9$ & $103.0 \pm 14.7$ & $163.0 \pm 6.7$ & $118.8 \pm 3.7$ \\
\hline & $\mathrm{T}_{4}$ & $106.3 \pm 8.2$ & $120.0 \pm 7.9$ & $184.0 \pm 8.9$ & $136.8 \pm 3.8$ \\
\hline & $\mathrm{T}_{5}$ & $110.5 \pm 5.2$ & $122.3 \pm 4.9$ & $204.0 \pm 7.6$ & $145.6 \pm 4.5$ \\
\hline & $\operatorname{LSD}(p=0.05)$ & 1.82 & 2.46 & 4.96 & 8.5 \\
\hline \multirow{6}{*}{$\mathrm{Zn}$} & $\mathrm{T}_{1}$ & $16.0 \pm 3.1$ & $18.0 \pm 3.1$ & $22.5 \pm 2.3$ & $18.8 \pm 2.7$ \\
\hline & $\mathrm{T}_{2}$ & $21.3 \pm 2.6$ & $18.0 \pm 0.8$ & $24.8 \pm 6.1$ & $21.3 \pm 2.7$ \\
\hline & $\mathrm{T}_{3}$ & $20.8 \pm 1.5$ & $18.0 \pm 1.8$ & $24.8 \pm 2.0$ & $21.2 \pm 2.7$ \\
\hline & $\mathrm{T}_{4}$ & $21.3 \pm 2.7$ & $21.5 \pm 3.7$ & $29.3 \pm 8.1$ & $24.0 \pm 3.7$ \\
\hline & $\mathrm{T}_{5}$ & $21.5 \pm 2.0$ & $23.5 \pm 7.5$ & $29.3 \pm 8.4$ & $24.8 \pm 3.2$ \\
\hline & $\operatorname{LSD}(p=0.05)$ & 0.65 & 0.85 & 0.90 & 0.41 \\
\hline \multirow{6}{*}{$\mathrm{Cu}$} & $\mathrm{T}_{1}$ & $3.8 \pm 0.9$ & $4.8 \pm 0.9$ & $10.0 \pm 2.1$ & $6.2 \pm 0.27$ \\
\hline & $\mathrm{T}_{2}$ & $5.8 \pm 1.5$ & $5.8 \pm 0.5$ & $13.8 \pm 1.5$ & $8.4 \pm 0.37$ \\
\hline & $\mathrm{T}_{3}$ & $5.3 \pm 0.5$ & $5.0 \pm 0.8$ & $13.5 \pm 4.2$ & $7.9 \pm 0.39$ \\
\hline & $\mathrm{T}_{4}$ & $6.0 \pm 1.4$ & $6.0 \pm 0.8$ & $14.8 \pm 2.2$ & $8.9 \pm 0.41$ \\
\hline & $\mathrm{T}_{5}$ & $6.0 \pm 1.8$ & $6.5 \pm 0.5$ & $17.0 \pm 3.4$ & $9.8 \pm 0.5$ \\
\hline & $\operatorname{LSD}(p=0.05)$ & 0.18 & 0.34 & 0.32 & 0.55 \\
\hline
\end{tabular}

In contrast, phosphorus content in leaf did not vary significantly among the treatments during different years. Potassium content was significantly higher in treatment $\mathrm{T}_{5}$ as compared to $\mathrm{T}_{1}$, the mean values were recorded as $0.61,0.56$ and 0.66 per cent in 2008-09, 2009-10 and 2010-11, respectively. The range of micronutrients viz. $\mathrm{Fe}, \mathrm{Mn}, \mathrm{Zn}$ and $\mathrm{Cu}$ content in leaves were 105.5 to $175.0,63.8$ to 204.0 , 16.0 to 29.3 and 3.8 to $17.0 \mathrm{ppm}$, respectively. The pooled mean value of $\mathrm{Fe}, \mathrm{Mn}, \mathrm{Zn}$ and $\mathrm{Cu}$ in $\mathrm{T}_{5}$ viz. $167.2,145.6,24.8$ and $9.8 \mathrm{ppm}$ were significantly higher than $\mathrm{T}_{1}(127.4,102.0,18.8$ and $6.2 \mathrm{ppm}$, respectively). All the micronutrients content in leaves increased marginally over the years (Table 4). This indicated a positive effect of soil nutrient management system comprising integration modules of organic and inorganic sources of nutrition with microbes. The leaf nutrient concentration followed almost similar trend of soil nutrient status. The effect of vermicompost was superior to FYM and organic mulching and microbes showed positive effect on nutrient build up in the soil and leaves. Studies inferred that tree foliar nutrient dynamics and its management is an essential management tool for rectifying any deficiency and thereby tree growth, yield and sustainability under diverse agroecological region (Rodrigues et al., 2011). 


\section{Conclusions}

This study revealed that the soil fertility, foliar nutrient concentrations and soil enzyme activities were significantly influenced by the application of organic and inorganic fertilizer amendments in mango orchard soil of low fertility status. Soil nutrient status was highest in the treatments where vermicompost and microbial inoculants were used as a component. Lowest fertility status was observed where only FYM and inorganic fertilizer were applied without consideration of other organics sources. In general, the soil and leaf nutrients were improved over the years. Dehydrogenase activity was significantly higher in microbial inoculants treated soil as compared to FYM + inorganic substrates. Surface soil $(0-10 \mathrm{~cm})$ showed higher dehydrogenase activity (1.29 to $\left.1.85 \mathrm{TPF} \mathrm{g}^{-1} \mathrm{~h}^{-1}\right)$ in all the treatments as compared to lower soil depths. Vermicompost emerged as more important organic input than FYM in soil nutrient management strategy as a function of crop residues management. Thus, to sustain the longterm fertility of orchard soil and soil and leaf nutrient dynamics, application of vermicompost along with $\mathrm{N}_{2}$ fixers and $\mathrm{P}$ solubilizing microorganisms and organic mulching should be integrated with NPK fertilizers.

\section{Acknowledgements}

Authors acknowledge the support and facilities provided by the Director, CISH, Lucknow during the course of this study. We also acknowledge all of our colleagues who helped directly or indirectly in carrying out the study. We gratefully acknowledge the anonymous reviewers for their constructive suggestions for improving the quality of the manuscript.

\section{References}

Adak, T., Sachan, R.S. 2009. Effect of co-inoculation of Sinorhizobium meliloti and Bacillus megaterium on yield and nutrient uptake of fenugreek (Trigonella foenum-graecum L.) in Mollisol soil. Journal of Medicinal and Aromatic Plant Sciences. $31,124-130$.

Albiach, R., Canet, R., Pomares, F., Ingelmo, F. 2001. Organic matter components and aggregate stability after the application of different amendment to a horticultural soil. Bioresource Technology. 76, 125-129.

Arancon, N.Q., Edwars, C.A., Bierman. P. 2006. Influences of vermicomposts on field strawberries: 2. Effects on soil microbiological and chemical properties. Bioresource Technology. 97, 831-840.

Atiyeh, R.M., Subler, S., Edwards, C.A., Bachman, G., Metzger, J.D., Shuster, W. 2000. Effects of vermicomposts and compost on plant growth in horticultural container media and soil. Pedobiologia. 44, 579-590.

Basak, B.B., Biswas, D.R., Rattan, R.K. 2012. Comparative Effectiveness of Value-added Manures on Crop Productivity, Soil Mineral Nitrogen and Soil Carbon Pools under MaizeWheat Cropping System in an Inceptisol. Journal of the Indian Society of Soil Science. 60, 288-298.

Basak, B.B., Biwas, D.R., Sharmistha, Pal. 2013. Soil biochemical properties and quality as affected by organic manures and mineral fertilizers in soil under maize-wheat rotation. Agrochimica. 57, 49-66.

Bhriguvanshi, SR., Adak, T., Kumar, K., Singh, V K., Singh A ., Singh, VK. 2012. Soil moisture, organic carbon and micronutrient dynamics and their interrelationship in drip irrigated mango orchard. Journal of Soil and Water conservation 11(4), 316-322. 
Binet, F., Trehem, P. 1992. Experimental microcosm study of the role of Lumbricus terristris on nitrogen dynamics in cultivated soils. Soil Biology and Biochemistry. 24, 1501-1506.

Casida, L.E., Klein, D.A., Santero, T. 1964. Soil dehydrogenase activity. Soil Science. 98, 371376.

Chu, H., Lin, X., Fujii, T., Morimoto, S., Yagi, K., Hu, J., Zhang, J. 2007. Soil microbial biomass, dehydrogenase activity, bacterial community structure in response to long-term fertilizer management. Soil Biology and Biochemistry. 39, 2971-2976.

Hanway, J.J., Heidel, H. 1952. Soil analysis methods as used in Iowa State College, Soil Testing Laboratory, Iowa State College Bull. 57, 1-131.

Kumar, K., Singha, A., Adak, T., Singh, V.K. 2011. Nutrient status of mango orchard soil as affected by integrated nutrient management. In: Proceedings of Global Conference on Augmenting Production and Utilization of Mango: Biotic and Abiotic Stresses held during June 21-24, 2011, at CISH, Rehmanhkeha, Lucknow. pp 95-96.

Kumar, M., Kumar, P., Bohra, D.C. 2009. Effect of land use systems on soil properties and relationship between soil organic carbon and available nutrients in typical arid soils of Rajasthan. Annals of Arid Zone. 48, 25-28.

Lindsay W.L., Norvell, W.A. 1978. Development of DTPA soil test for zinc, iron, manganese and copper. Soil Science Society of American Journal. $42,421-428$

Mandal, A., Patra, A.K., Singh, D., Swarup, A., Masto, R.E. 2007. EVect of long-term application of manure and fertilizer on biological and biochemical activities in soil during crop development stages. Bioresource Technology. 98, 3585-3592.
Manjaiah, K.M., Singh, D. 2001. Soil organic matter and biological properties after 26 years of maizewheat-cowpea cropping as affected by manure and fertilization in a cambisol in semiarid region of India. Agriculture Ecosystem and Environment. $86,155-162$

Olsen, S.R., Cole, C.V., Watanabe, F.S., Dean, L. A. 1954. Estimation of available phosphorus in soils by extraction with sodium bicarbonate. U. S. Department of Agriculture Circular, pp. 939.

Piper, C.S. 1967. Soil and plant analysis. Asia Publishing House, Bombay, India.

Pramanik, P., Ghosh, G.K., Chung, Y.R. 2010. Changes in nutrient content, enzymatic activities and microbial properties of lateritic soil due to application of different vermicomposts: a comparative study of ergosterol and chitin to determine fungal biomass in soil. Soil Use and Management. 26, 508-515.

Pramanik, P., Ghosh, G.K., Ghosal, P.K., Banik, P. 2007. Changes in organic-C, N, P and $K$ and enzyme activities in vermicompost of biodegradable organic wastes under liming and microbial inoculants. Bioresource Technology. 98, 2485-2494.

Rahman, M.H., Holmes, A.W., McCurran, A.G., Saunders, S.J. 2011. Impact of Management Systems on Soil Properties and Their Relationships to Kiwifruit Quality. Communication in Soil Science and Plant Analysis. 42, 332-357.

Rahman, M. H., Sugiyama, S. 2008. Dynamics of microbial community in Japanese Andisol of apple orchard production systems. Communications in Soil Science and Plant Analysis. 39, 1630-1657.

Ravishankar, H., Kumar, K., Singha, A., Adak, T. 2010. Integrated Nutrient Management in Mango and Guava. Indian Journal of Fertilizer. 6, 12-21. 
Rodrigues, M.Â., Lopes, J.I., Pavão, F.M., Cabanas, J.E., Arrobas, M. 2011. Effect of Soil Management on Olive Yield and Nutritional Status of Trees in Rainfed Orchards. Communication in Soil Science and Plant Analysis. 42, 993-1007.

Singh, V.J., Sharma, S.D., Kumar, P., Bhardwaj, S.K., Raj, H. 2010. Conjoint application of bio-organic and inorganic nutrient sources for improving cropping behaviour, soil properties and quality attributes of apricot (Prunus armeniaca). Indian Journal of Agricultural Sciences. 80, 981-987.

Subbiah, B.V., Asija, G.L. 1956. A rapid procedure for determination of available nitrogen in soils. Current Science. 25, 259-260.

Tejada, M., Gomez, I., Hernández, T., García, C. 2010. Utilization of vermicomposts in soil restoration: effects on soil biological properties. Soil Science Society of America Journal. 74, 525-532.
Tiwari, S.C., Tiwari, B.K., Mishra, R.R. 1989. Microbial populations, enzyme activities and nitrogen, phosphorus and potassium enrichment in earthworm casts and in surrounding soil of a pineapple plantation. Biology and Fertility of Soils. 8, 178-182.

Zahir, Z.A, Arshad, M., Frankenberger, W.T. 2004. Plant growth promoting rhizobacteria: applications and perspectives in agriculture. Advances in Agronomy. 81, 97-168.

Zhang, B.G., Li, G.T., Shen, T.S., Wang, J.K., Sun, Z. 2000. Changes in microbial biomass $\mathrm{C}, \mathrm{N}$ and $\mathrm{P}$ and enzyme activities in soil incubated with the earthworm Metaphire guillelmi or Eisenia fetida. Soil Biology and Biochemistry. 32, 2055-2062. 